\title{
The Mediterranean Sea in the martime Policy of the Byzantine emperors in the VI Century
}

\section{Morze Śródziemne w polityce morskiej cesarzy wschodniorzymskich w VI stuleciu}

\author{
Marcin Böhm \\ The Institute of History, The Faculty of History and Pedagogy, Opole University, \\ 2 Strzelców Bytomskich Str., 45-084 Opole, Poland \\ E-mail address: mabohm@wp.pl
}

\begin{abstract}
The turn of the V and VI century AD was an important period in the history of the Roman Empire fleet. The Mediterranean Sea once again became, a body of water full of competitive fleets, threatening the remnants of the Western Roman Empire and the provinces of Byzantium. On the emperors of the East, in Constantinople, fell to conserve the heritage of Rome, and the conduct of maritime policy in the Mediterranean. They had to contend with the fleets of Vandals, Goths, who quickly discovered the benefits of having their own naval forces, which helped them to master most of the islands in the western Mediterranean. Only Justinian I broke the losing streak of the Roman fleet, going on the offensive on the sea, in his attempt to reconstruct the old empire. It was a very long process that ended successfully.
\end{abstract}

Keywords: Byzantium; Byzantine Navy; Vandal Kingdom; Justinian I

\section{STRESZCZENIE}

Przełom wieku V i VI w. n.e. był ważnym okresem dla dziejów floty Cesarstwa Rzymskiego. Morze Śródziemne z rzymskiego mare nostrum, ponownie stało się wtedy akwenem na którym pojawiły się konkurencyjne floty, zagrażające resztkom Cesarstwa Zachodniorzymskiego i prowincjom kształtującego się powoli Bizancjum. To właśnie na cesarzy panujących na Wschodzie, w Konstantynopolu, spadł obowiązek utrzymania spuścizny Rzymu, w prowadzeniu polityki morskiej na obszarze Morza Śródziemnego. Musieli zmagać się oni z flotami Wandalów, Gotów, którzy szybko odkryli korzyści płynące z posiadania własnych sił morskich, które pomogły im opanować większość wysp w zachodniej części śródziemnomorza. Dopiero Justynian I przełamał złą passę rzymskiej floty, przechodząc do ofensywy na morzu, w swojej próbie rekonstrukcji dawnego imperium. Był to proces bardzo długotrwały, który zakończył się powodzeniem, ale połowicznym, bowiem odniesiony w działaniach lądowych sukces, nie pomógł $w$ budowie stabilnej $i$ licznej floty wojennej, przypominającej swoją strukturą dawną flotę Republiki i Cesarstwa.

Stowa kluczowe: Bizancjum, marynistyka, Wandalowie, Justynian I. 


\section{WPROWADZENIE}

Republika, a następnie Cesarstwo Rzymskie w wyniku kilkuwiekowych podbojów opanowało cały akwen Morza Śródziemnego, skutecznie eliminując zarówno dawne morskie potęgi Kartaginę, Egipt, jak i plagę piractwa. Na całym tym obszarem zapanował pax romana i Rzymianie mieli wszystkie podstawy aby Morze Śródziemne nazywać mare nostrum. Potężna rzymska flota dbała o bezpieczeństwo morskich szlaków handlowych, które biegły do Rzymu, a później również do nowej stolicy-Konstantynopola. Stan ten trwał przez stulecia, aż do przybycia nowych przeciwników germańskich Wandali, Wizygotów i Ostrogotów w V wieku. Ludzie ci rzucili wyzwanie Rzymowi także na Morzu Śródziemnym, budując floty, przy pomocy których skutecznie destabilizowali sytuację w regionach nadmorskich cesarstwa i wcześniej niedostępnych dla nich wyspach. Germanom sprzyjał podział cesarstwa, które rozpadło się pod koniec IV wieku na dwie części: Wschodnią i Zachodnią. Po upadku Cesarstwa Zachodniorzymskiego, na panujących w Konstantynopolu cesarzy spadł obowiązek ratowania i utrzymania spuścizny morskiej dawnego imperium. Jeden z nich Justynian I postanowił odbudować cesarstwo w jego dawnym kształcie. Mógł tego jedynie dokonać dysponując całkowitym panowaniem na morzu, które mogła mu zapewnić silna flota wojenna. To dokonania tego właśnie cesarza na polu militarnym (a raczej jego wybitnych dowódców), długie panowanie i polityka morska odcisnęły istotny wpływ na politykę jego najbliższych następców. Nim jednak przejdziemy do omówienia polityki i działań morskich cesarzy panujących w VI wieku w stolicy nad Bosforem, trzeba w tym miejscu przybliżyć morską sytuacje Rzymian pod koniec poprzedniego stulecia.

Pomiędzy rokiem 439 a 477 Wandalowie pod wodzą swego najwybitniejszego władcy Genzeryka, zbudowali morskie imperium sięgające od Afryki Północnej, po Baleary na Zachodzie [1-3]. Zdecydowane działania Genzeryka, który dążył w tym okresie do opanowania największych wysp Morza Śródziemnego Sycylii, Sardynii i Korsyki oraz kpił sobie z sił morskich Rzymian, wymusiły reakcję Cesarstwa Wschodniorzymskiego. Konstantynopol w roku 468 przygotował kampanie wojenną, której celem było zniszczenie państwa Wandalów. Floty wschodniorzymskie miały przewieźć do Afryki Północnej żołnierzy, oraz utrzymać odzyskane przez comesa Marcelina w roku 465 i 466 wyspy Sardynie i Sycylię [1,2,4-7] które wcześniej wpadły w ręce Genzeryka. Początkowo stojącemu na czele wyprawy Basiliskosowi sprzyjało szczęście. Jednak dalsze błędy rzymskich dowódców, wynikające z nieznajomości wód opływających Półwysep Bon, a także zastosowanie przez Wandali branderów dla zniszczenia floty cesarskiej w pobliżu Kartaginy, przyczyniły się do fiaska całej wyprawy [1-7]. Na początku lat siedemdziesiątych V wieku wschodni Rzymianie podjęli kolejną próbę wyparcia Wandalów z Trypolitanii, która zakończyła się podobnie jak pierwsza [ 6-9]. Panujący w Konstantynopolu Leon I (457-474) wyczerpawszy możliwości militarne zmuszony został uznać władze Genzeryka nad opanowanym przez niego obszarem i niemal całą zachodnią częścią Morza Śródziemnego $[2,3,7]$. Pokój między Cesarstwem Wschodniorzymskim a Wandalami na morzu okazał się trwały, a obalić miał go dopiero Justynian I.

Nie wiemy, czy po stracie licznej floty w nieudanych próbach wypędzenia Wandalów z Afryki Północnej, udało się cesarzom z Konstantynopola odbudować swój morski potencjał. Po upadku Cesarstwa Zachodniorzymskiego w 476 roku, mamy dowody na obecność niewielkich sił morskich Bizantyńczyków na Adriatyku. O ich rozmiarach świadczyć może panika jaka wybuchła wśród cesarskich dworzan, na wieść o zajęciu przez Teodoryka Wielkiego Dyrrachium. Zakazano mu wtedy posuwać się dalej i zajmować znajdujące się w tym mieście okręty $[3,10]$. Obawy konstantynopolitańskich notabli nie były bezpodstawne, 
bowiem pod koniec $\mathrm{V}$ wieku, w stoczniach Bizancjum i Italii powstał nowy typ okrętów. Dromon, bo to o nim mowa kontynuował tradycje szkutnicze Greków i Rzymian, jednak istotne zmiany technologiczne wprowadzone przez ówczesnych szkutników, czyniły go jednostką nowej klasy. Jego głównym atrybutem była prędkość, która osiągnięto kosztem ciężaru okrętu. Okręty tego rodzaju były jednorzędowymi galerami, z pełnym pokładem, pod którym znajdowali się wioślarze. Wyposażano je początkowo tylko $\mathrm{w}$ jeden maszt $\mathrm{i}$ ożaglowanie łacińskie. W okresie późniejszym następowała powolna ewolucja tego typu okrętów. Dodano dromonowi drugi maszt i drugi rząd wioseł, co znacznie zwiększało prędkość statku, upodobniając go przy tym rozmiarami do klasycznej biremy [3,11-14].

Dromon nie był, podobnie jak wcześniejsze galery typu trirema czy birema, wyposażony w wykonany z metalu taran, lecz posiadał specjalnie wzmocniony dziób, który różnił się znacząco od wcześniejszych konstrukcji. Nowy dziób był tak wykonany, aby zbytnio nie obciążać konstrukcji okrętu. Nie pozwalał na wykonywanie klasycznego manewru taranowania, służył raczej do niszczenia wioseł jednostki przeciwnika, co unieruchamiało ją w czasie bitwy, tak że stawała się łupem bizantyńskich łuczników i piechoty morskiej. Można było go też użyć do podniesienia i wywrócenia mniejszych jednostek przeciwnika [3].

Pomimo starań notabli z Bizancjum, dromony znalazły się zapewne w rękach zarówno Teodoryka, jak i Odoakra, odpowiedzialnego za likwidacje cesarstwa na Zachodzie. Na szczęście dla Konstantynopola obaj zwrócili się przeciwko sobie, korzystając z dromonów w czasie walk pod Rawenną w latach 491- 493, z których zwycięsko wyszedł Teodoryk [3, 15,16]. Pan Ostrogotów został twórcą nowego organizmu państwowego w Italii, który obejmował także Sycylię, którą w roku 477 Odoaker uzyskał kosztem Wandalów[2:144-145; 7:30-31]. Niestety nie wiemy, jak liczną flotą dysponował w tym okresie Teodoryk zwany później Wielkim. Siły morskie Ostrogotów miały za zadanie utrzymać przede wszystkim połączenie z Sycylią, będącą spichlerzem Italii[7:32]. Możemy jedynie spekulować, iż były znacznie skromniejsze niż te, którymi dysponowali następcy Genzeryka i ich głównym zadaniem było strzeżenie Cieśniny Mesyńskiej i biegnących przez nią dróg handlowych.

Wchodzące w VI stulecie Cesarstwo Wschodniorzymskie nie było już jedynym państwem w basenie Morza Śródziemnego, które dysponowało wojennymi siłami morskimi. Prócz słabnącego północnoafrykańskiego państwa Wandalów, nowy Rzym miał także konkurencje w postaci królestwa Ostrogotów, które zajmowało obszar Półwyspu Apenińskiego. Potencjalna współpraca tych dwóch sił mogła zagrażać bezpieczeństwu cesarstwa. Zarówno Wandalowie, jak i Ostrogoci dążyli do niej, co znalazło wyraz w małżeństwie wandalskiego króla Trasamunda z siostrą Teodoryka Wielkiego, Amalafredą, które doszło do skutku około 500 roku [2,7,8,17]. Rezultatem tego związku było ponowne przekazanie części zachodniej części Sycylii z Lilybaeum Wandalom, którą Amalfreda wniosła jako swoje wiano. Potwierdza to znaleziona na tej wyspie inskrypcja o treści fines inter Vandalos et (Go)thos, co wskazuje jednoznacznie na istnienie na Sycylii późniejszej granicy między tymi dwoma germańskimi ludami[2,7,30-32]. Teodorykowi Wielkiemu, który nie dysponował wystarczająco liczną flotą wojenną, zależało na pomocy okrętów wandalskich, w ewentualnym konflikcie z Cesarstwem Wschodniorzymskim, czy w jego polityce dotyczącej Wizygotów [2].

Nowy cesarz Anastazjusz I (491-518) musiał zmierzyć się z tym zagrożeniem. Sprzymierzył się w tym celu z Frankami, którzy dążyli do wywalczenia sobie dojścia do Morza Śródziemnego, kosztem tuluzańskiego państwa Wizygotów. Naturalnymi wrogami Franków byli wspierający Wizygotów, Ostrogoci Teodoryka Wielkiego. Cesarz którego relacje $\mathrm{z}$ Teodorykiem $\mathrm{w}$ pierwszej dekadzie VI stulecia nie były najlepsze, postanowił wesprzeć swoich aliantów, którzy odnieśli spektakularny sukces w bitwie pod Vouillé w 507 
roku [2,16]. W 508 roku wysłał 100 dromonów, których zadaniem było spustoszenie wybrzeża znajdującej się w rękach Teodoryka Italii $[18,19]$. Działalność floty Anastazjusza uniemożliwiła Ostrogotom skuteczniejsze przyjście z pomocą Wizygotom, dotkliwie rozbitym po wspomnianej wyżej bitwie. Teodoryk nie posiadał silnej floty wojennej, skoro pozwolił na grabieżcze działania floty cesarskiej [3:13]. Jego wandalski sojusznik Trasamund, na pomoc okrętów którego liczył władca Ostrogotów, zawiódł pokładane w nim nadzieje, zachowując bierność w czasie rajdów floty Anastazjusza na ziemie należące do Teodoryka. Trasamund wmieszał się ponadto $\mathrm{w}$ wizygockie spory dynastyczne, które toczyły się $\mathrm{w}$ Hiszpanii w latach 509-510 [2,16]. Działania wandalskiego króla godziły w politykę prowadzoną przez jego szwagra w Langwedocji i na Półwyspie Iberyjskim. Do otwartej wojny wandalsko-gockiej doszło jedynie na Sycylii, w rejonie Libybaeum [16].

Konstantynopol nie był w stanie wykorzystać, zaistniałego kryzysu w obozie swoich przeciwników. Anastazjusz, być może częściowo odpowiedzialny za załamanie się relacji między Ostrogotami a Wandalami, po roku 508 wykazał sporą bierność w działaniach na Morzu Śródziemnym (Według Prokopiusza Trasamund miał być specjalnym przyjacielem cesarza Anatazjusza. Procopius. [17]). Ponowne zbliżenie między Teodorykiem a Trasamundem, które nastąpiło po roku 510, nie było korzystne dla politycznych interesów cesarstwa, zagrażało bowiem bezpieczeństwu jego morskich granic. Szczęśliwie dla Anastajzusza do końca jego panowania floty Wandalów, nie podejmowały żadnych działań wymierzonych w cesarstwo.

Flota wysłana przez Anastajusza w roku 508 do Italii, po wykonaniu swojego zadania powrócić musiała do swoich baz na Bałkanach i w stolicy imperium. Brak działań wojennych wymierzonych we wrogów cesarstwa, jak również niepokoje społeczne spowodować musiały znaczący spadek jej morale. Najdobitniej o tym świadczy udział części floty w buncie Witaliana w latach 513-515. Ten zdolny dowódca zbuntował się przeciwko władzy cesarza $\mathrm{i}$ na czele wojsk trackich zwrócił się przeciwko stolicy. W 514 zgromadził 200 okrętów, z których cześć mieli mu dostarczyć Słowianie, a pozostałe zebrał zapewne z portów nad Morzem Czarnym i skierował je na Bosfor [8,20-22]. Jego celem było odcięcie stolicy od strony lądu i morza. Anastazjusz oblężony w Konstantynopolu, poszedł na ustępstwa i mianował Witaliana magister militum per Thracias, oraz przekupił złotem i obietnicami zwołania soboru kościoła w Konstantynopolu w lipcu 515 [20]. Cesarz nie zdołał się wywiązać $\mathrm{z}$ tej obietnicy i Witalian w drugiej połowie 515 roku ponownie pojawił się pod stolicą. Zajął miasto Sycae leżącą po drugiej stronie Złotego Rogu, gdzie rozbił obóz. Anastazjusz ściągnął do stolicy Marinusa, dawnego praefectura praetorio Orientis, któremu powierzył dowództwo swojej floty i wojsk lądowych [20]. Okręty które przekazał Marinusowi Anastazjusz musiały pochodzić z eskadry podległej bezpośrednio cesarzowi, jak również z Azji Mniejszej do której nie dotarli zwolennicy Witaliana. Marinus nie zawiódł oczekiwań cesarza, w bitwie morskiej u wejścia do Złotego Rogu rozbił flotę uzurpatora, a następnie wylądował pod Sycae, gdzie rozpędził wojska lądowe Witaliana [20,23]. O sukcesie działan floty Marinusa przesądzić miało zastosowanie przez jego ludzi mieszanki zapalającej, której twórcą był Proklus Ateńczyk [23,24].

Mamy zatem mocne dowody na istnienie floty Cesarstwa Wschodniorzymskiego na przełomie V i VI wieku. Problemy pojawiają się gdy pragniemy określić czy za panowania Anastazjusza mamy do czynienia z jakąś planowaną polityką morską, czy raczej ze zbiorem przypadkowych działań tego władcy. Wiemy z całą pewnością, iż siły cesarstwa dysponowały nowoczesnymi okrętami-dromonami, które przyczynić się musiały w dużej mierze do sukcesu Marinusa. Być może jednostki Witaliana nie były w stanie sprostać lepszym okrętom podległym cesarzowi. Nie wiemy także, które porty były kluczowymi bazami floty cesarskiej. 
Kluczowy musiał być Konstantynopol, a dla operacji wymierzonych w Ostrogotów, również Dyrrachium. To zapewne $\mathrm{w}$ stolicy przeprowadzano eksperymenty $\mathrm{z}$ różnymi mieszankami zapalającymi, z których jedna była współodpowiedzialna za zwycięstwa nad flotą Witaliana.

Następca Anastazjusza Justyn I (518-527) przez całe swoje panowanie nie przejawiał większego zainteresowania sprawami morskimi. Sprzyjała takiej postawie sytuacja wewnętrzna zarówno w państwie Wandalów, jak i w królestwie Teodoryka. Inna sprawą było stałe zagrożenie ze strony państwa perskiego, szczególnie dla wschodnich i przy tym najbogatszych prowincji cesarstwa, które wymagało baczniejszej uwagi i troski cesarza. Śmierć Trasamunda w 523 i objęcie władzy nad Wandalami przez Hilderyka, zwiastowało przełom w relacjach na linii Kartagina-Rawenna. Hilderyk przeszedł do obozu cesarskiego, odcinając się od proostrogockiej polityki swego poprzednika. Wdowa po Trasamundzie Amalafreda była ostatnią przeszkodą w całkowitym zerwaniu z Teodorykiem. Nowy król Wandalów obawiając się jej wpływów wśród Wandalów, rozkazał ją zabić w 525 roku $[2,7,16]$. W wandalskich rękach pozostało Lilybaeum, które zapewniało Hilderykowi dodatkowy punkt wyjścia do ewentualnych morskich działań wymierzonych w Sycylię, czy w Italię [7].

Hilderyk poczynał sobie tak śmiało wobec partii progockiej w Afryce Północnej i dzierżył Libyaeum, ponieważ zapewne świadom był niewielkich możliwości sił morskich Teodoryka. Władca Ostrogotów zaskoczył swoich przeciwników, wydając wiosną 526 rozkaz wybudowania 1000 dromonów, których głównym zadaniem miał być transport zboża i obrona przed wrogimi okrętami. Załogi, a przede wszystkim wioślarzy tych okrętów Teodoryk rozkazał rekrutować wśród ludzi wolnych, a nawet niewolników. Miejscem koncentracji swojej nowej floty Teodoryk uczynił Rawennę. Okręty wojenne Ostrogotów miały stawić się w tym mieście 13 czerwca 526 roku [2,7,16,25]. Teodoryk być może zamierzał osobiście poprowadzić swoją flotę $\mathrm{w}$ ataku na Kartagine, lecz choroba i rychła śmierć pokrzyżowała te plany. Zarówno Justyn I, jak i sympatyzujący z nim Hilderyk uniknęli w ten sposób konfrontacji z flotą ostrogocką, która pozostała w swoich portach, gdyż Amalasunta nie kontynuowała polityki ojca $[2,18,26]$. Nie wiemy gdzie powstało owe 1000 dromonów i w których portach Italii, jak również czy plan ich budowy zrealizowano przed śmiercią Teodoryka. Pewną możliwość dotyczącą miejsc produkcji okrętów nasuwa nam informacja o koncentracji floty w Rawennie, podana przez źródła. Na jej podstawie możemy spekulować, iż Teodoryk wydał polecenie dotyczące budowy nowych dromonów jedynie adriatyckim portom, leżącym w północnej części Półwyspu Apenińskiego. Unikał w ten sposób zagrożenia ze strony flot wandalskich i floty cesarskiej, które mogły pokrzyżować jego plany, gdyby budował je pobliżu potencjalnego frontu działań, czyli na Sycylii i portach leżących nad Morzem Tyrreńskim. Nie możliwe wydaje się jednak zbudowanie floty liczącej tysiąc okrętów w ciągu paru miesięcy, przy ograniczonym zapleczu stoczniowo-portowym. Bardziej prawdopodobna wydaje się adaptacja zarekwirowanych przez Ostrogotów jednostek handlowych, czy rybackich, które znajdować się musiały w portach nad Adriatykiem.

Śmierć cesarza Justyna w 527 roku, po której tron objął Justynian I (527-565) nie zwiastowała zmiany polityki Konstantynopola w sprawach dotyczących Morza Śródziemnego. Zmiana nastąpiła po obaleniu życzliwego cesarstwu władcy Wandalów Hilderyka w roku 430. Jego miejsce zajął Gelimer, niezbyt przychylnie nastawiony do Konstantynopola. Justynian postanowił wystąpić jako obrońca praw Hilderyka do tronu i wymusić na Gelimerze ustępstwa na drodze dyplomatyczne, lecz nowy władca wandalski pozostał głuchy na sugestie cesarza [2,26,28,33]. Przez okres lat 530-532 cesarz nie był w stanie wystąpić zbrojnie na korzyść Hilderyka, ponieważ na wschodzie trwały walki z Persami, zaś w Konstantynopolu wybuchło powstanie Nika [2,28,29,33]. Wszystkie te 
przeszkody nie zniechęciły jednak cesarza. Pod koniec 532 i na wiosnę 533 Justynian gromadził w stolicy siły lądowe i okręty, na wojnę z Gelimerem [27]. Na czele korpusu ekspedycyjnego postawił cesarz swego najwybitniejszego dowódce Belizariusza, weterana wojen z Persami. Pod jego dowództwo trafiło 10000 żołnierzy piechoty i 5000 konnych, których na miejsce akcji przewieźć miało 500 statków transportowych, których osłonę stanowić miały 92 dromony z dodatkowymi 2000 wioślarzy, pełniących również rolę piechoty morskiej [2,27,28]. Okręty zgromadzone na tą wyprawę pochodziły z różnych części cesarstwa: z Egiptu, Wysp Jońskich i Cylicji. Ogromna flota transportowa wyruszyła w czerwcu do Afryki Północnej. Jej droga biegła przez Morze Egejskie, wokół Peloponezu a następnie ku Sycylii [27].

Flota zgromadzona przez cesarza i przeznaczona do uderzenia na Wandalów, od samego początku cierpiała na braki logistyczne. Najważniejszymi było zaopatrzenie w psujący się chleb i nieumiejętność właściwego przechowywania wody pitnej, która po kilku dniach nie nadawała się do spożycia [2,27]. Takie elementarne błędy wystawiają złą ocenę flocie Justyniana I, która najwidoczniej nie dysponowała żadnym doświadczeniem w prowadzeniu tego typu operacji. Zbieranina ludzi i okrętów, którą zgromadził w Konstantynopolu cesarz, wymagała jakiegoś ujednolicenia dowodzenia i zająć się tym miał Belizariusz. Zadanie było trudne i czasochłonne. Belizariusz musiał zapewnić swoim ludziom wystarczającą ilość pokarmu i płynów, aby zachowali sprawność bojową, co nie było łatwym zadaniem jeśli weźmiemy pod uwagę, że floty Wandalów miały swoje stałe bazy na wyspach w zachodniej części Morza Śródziemnego [7,39]. Bizantyńczykom sprzyjało szczęście, bowiem królowa Amalasunta, wrogo nastawiona do Wandalów, którzy zamordowali jej ciotkę, zezwoliła im na skorzystanie z Sycylii, jako bazy przed uderzeniem na Afrykę Północną. Pozwoliła również na zakup wierzchowców dla jazdy Belizariusza, niezbędnych dla powodzenia wyprawy przeciwko Gelimerowi [2,7,27,39].

Gelimer spodziewał się interwencji zbrojnej Justyniana. Nie wiedział jednak ta kiedy miała nastąpić. Na niekorzyść króla Wandalów działała również sytuacja wewnętrzna w jego państwie. W Trypolitanii w roku 532 zbuntował się przeciwko jego władzy niejaki Pudencjusz. Rebelie wsparli Bizantyńczycy, walnie przyczyniając się do sukcesu tego buntownika [2,27]. Groźniejsze jednak dla władzy Gelimera, było wystąpienie Godasa. Godas dawny niewolnik króla Gelimera, został mianowany przez niego namiestnikiem na Sardynii. W roku 533 opowiedział się przeciwko swemu panu i poprosił o pomoc wojskową Justyniana [2,27]. Gelimer nie mógł sobie pozwolić na utratę Sardynii, dlatego wysłał całą swoją flotę w silę 120 okrętów, pod dowództwem swego brata, aby ten spacyfikował buntowników i odzyskał tą wyspę [2,27]. Odesłanie całej floty wojennej i pozostawienie bez morskiej ochrony wybrzeża Afryki Północnej było swoistego rodzaju prezentem dla Belizariusza i jego ludzi, którzy najbardziej obawiali się morskiej zasadzki ze strony sił morskich Gelimera [2,27]. Tak bez przeszkód Bizantyńczycy wylądowali pod Caput Vada 31 sierpnia 533 $[2,27,33]$.

Belizariusz po opanowaniu przyczółka, rozpoczął marsz wzdłuż wybrzeża w kierunku Kartaginy. Flota towarzyszyła na morzu wojskom lądowym. Na wieść o przybyciu Belizariusza Gelimer, rozkazał stracić Hilderyka. Bitwa lądowa, która władca Wandalów wydał bizantyńskiemu dowódcy pod Ad Decimum zakończyła się jego sromotną porażką. Jej głównym rezultatem było opanowanie przez Belizariusza przedmieść Kartaginy, która nie była w żaden sposób przygotowana do obrony. Okręty Belizariusza dotarły pod Kartaginę prawie w tym samym czasie co wojska lądowe, lecz marynarze nie wkroczyli do miasta pierwsi, lecz oczekiwali na polecenia dowódcy, stojąc na kotwicy $\mathrm{w}$ miejscu zwanym 
Mandarkion. 15 września 533 marynarze wraz z siłami lądowymi zajęli stolice państwa wandalskiego $[2,27,33]$.

Gelimer stracił stolicę, lecz nie zamierzał się poddać. Ściągnął z Sardynii swego brata z cała jego flotą i wojskami lądowymi. Tzazon, bo to o nim mowa zdołał pokonać Godasa i krwawo rozprawić się pozostałymi przywódcami rebelii [2,27,33]. Przybycie jego sił, wzmocnionych zapewne wandalskimi garnizonami z Sycylii, dawało Wandalom nadzieje na przełamanie złej passy [2,27,33]. Zwycięstwo Belizariusza ostatecznie rozwiało te złudzenia. Siły morskie Bizantyńczyków po zajęciu Kartaginy odgrywały już marginalną rolę w dalszym przebiegu walk z Gelimerem.

Ograniczała się ona jedynie do kontroli i przechwytywania okrętów wandalskich, które nieświadome zagrożenia wpływały do portów tego miasta [27]. Poza tą kwestią Belizariusz zaniedbał działania patrolowe i wywiadowcze na morzu, co pozwoliło na lądowanie Wandalów przybyłych z Sycylii i na połączenie ich sił z Gelimerem. Ten błąd mógł przyczynić się do klęski całej bizantyńskiej ekspedycji. Upadek państwa Wandalów zniósł zagrożenie płynące ze strony ich flot dla bezpieczeństwa morskiego Cesarstwa Wschodniorzymskiego. Konstantynopolowi pozostał jeden konkurent na zachodzie, ostrogockie państwo rządzone przez następców Teodoryka Wielkiego.

W czasie walk Belizariusza w Afryce Północnej Ostrogoci zajęli opuszczone przez wandalskie oddziały Lilybaeum i przyłączyli je do należącej do nich części Sycylii [7,8,39]. Gdy upomniał się o ten region Belizariusz po zakończeniu walk z Gelimerem, spotkał się z niechęcią otoczenia gockiej królowej Amalasunty, które nie zamierzało oddać spornego terytorium Bizantyńczykom [39]. Do walk na Sycylii doszło dopiero w 535 r.. Justynian od nich rozpoczął wojnę przeciwko Ostrogotom, której celem było całkowite zniszczenie ich państwa. Na czele floty i sił lądowych skierowanych na tą wyspę, cesarz postawił wypróbowanego wcześniej Belizariusza. Cała Sycylia przeszłą pod władzę cesarstwa bez większych walk i miała stać się kolejnym punktem wyjścia do dalszych działań wymierzonych w ostrogocką Kalabrię [3,7,17]. Drugi front został otwarty w Dalmacji, którą zajął dla Bizancjum człowiek o imieniu Mundo $[16,17]$. Niestety Goci w tym rejonie przeszli do kontrofensywy i rozbili wojska Mundo, ponownie odbierając tą prowincje cesarstwu.

Justynian wysłał kolejną flotę pod dowództwem Konstantyna, której zadaniem było opanowanie Salony i Epidaurus, które utracił Mundo, leżących na adriatyckim wybrzeżu Bałkanów. Miejscem koncentracji nowej floty było Dyrrachium [3,16,17]. Salona była ważnym i strategicznie położonym portem, które dodatkowo dostarczało soli do Italii. Podobne znaczenie miało Epidaurus. Posiadanie tych portów zapewniało panowanie nad Adriatykiem. Konstantyn zdobył obydwa miasto, zbliżając się niebezpiecznie blisko Rawenny, co wywołało reakcje Witigisa, nowego władcy Ostrogotów. Wysłał on przy pomocy swojej floty składającej się z ploia makra, korpus ekspedycyjny, aby ten ponownie odzyskał Salone. Nim Goci dotarli na miejsce, ich okręty zostały rozpędzone przez flotę Konstantyna [3,16-18]. Ten sukces, jak również działania Belizariusza na południu Italii, pozwalały cesarstwu na dostarczanie stałych posiłków na front drogą morską [3]. Przewaga na morzu zadecydowała o utrzymaniu się w Rzymie Belizariusza w latach 537-538 [17]. Dominacja na Adriatyku, którą zapewniało cesarstwu posiadanie Dalmacji, przyczyniła się również do upadku Rawenny w 540, którą Belizariusz zagłodził dysponując siłami mniejszymi niż Witigis $[3,16,17]$

Nowy władca Ostrogotów Totila dostrzegł zapewne zależność między cesarskimi sukcesami,a nieposiadaniem silnej floty wojennej przez jego lud. Ofensywa jaką poprowadził do środkowej i południowej Italii w latach 542, rzuciła go aż pod Neapol, który młody król postanowił zdobyć. Justynian nieświadom postępów Gotów, wysłał do Italii dwie floty. 
Pierwsza pod dowództwem Demetriosa miała udać się na Sycylię. Jej dowódca zamiast na wyspę skierował się jednak do Rzymu i został zaskoczony przez dromony Totili pod Neapolem [3,17]. Dowodzona przez niego flota została zniszczona. Druga flota cesarska również skierowana została na Sycylię, gdzie jej dowódca Maksyminos spędził lato 542 roku i dopiero $z$ nadejściem jesieni wyruszył pod Neapol. Tam zaskoczyła go burza, która zniszczyła większość jego floty, a cześć okrętów wyrzuciła na brzeg w pobliże obozu Ostrogotów [17]. Stracone przez Maksyminosa okręty musiały zasilić budowaną przez Totilę flotę, której posiadanie walnie przyczyniło się do opanowania Neapolu wiosną 543 roku. Cesarstwo utraciło przewagę, jaką była dominacja na Morzu Śródziemnym. Totila okazał się zdolnym do prowadzenia skutecznych działań na morzu, co udowodnił zdobywając w 546 roku Rzym. Cesarskie miasto zostało wzięte, gdyż Totila przy pomocy swojej floty zablokował wszystkie dostawy żywności i posiłków, dostarczanych drogą morską z Bizancjum i Sycylii [3,17]. Belizariusz odzyskał Rzym przełamując blokadę Tybru przy pomocy 200 dromonów, które odpowiednio zabezpieczył drewnianymi parapetami, by chronić swoich żołnierzy i marynarzy [3,17]. Bizantyńczycy odzyskali na krótko inicjatywę na morzu i podjęli w 548 roku próbę przerzucenia dodatkowych sił z Bałkanów i Sycylii do południowej Italii. Ich lądowanie pod Rossano uniemożliwiła gocka kawaleria, jak również burza, która rozrzuciła okręty po wybrzeżu $[3,17]$.

W 548 Belizariusz został odwołany ostatecznie do Konstantynopola, ponieważ nie udało mu się pokonać Totili, który dzierżył w swoich rękach prawie cały Półwysep Apeniński. Jeden $\mathrm{z}$ dawnych podwładnych Belizariusza Indulf zbuntował się $\mathrm{w}$ tym samym roku $\mathrm{i}$ przeszedł na stronę Totili. Bunt Indulfa był o tyle groźniejszy, że dysponował on jaką́s flotą, która posłużyła Gotom do ataku na bizantyńską Dalmacje w roku 549. Namiestnik Salony Klaudianos, próbował zatrzymać rajd Indulfa, lecz jego flota poniosła porażkę i w panice uciekła do portu $[3,16,17]$. Indulf spustoszył wybrzeże i wrócił do Italii. Totila musiał być zadowolony z dokonań nowego sojusznika i powierzył mu dowództwo 47 ploia makra, które miały zaatakować Ankonę [17]. Być może rajd Indulfa na Dalmacje możemy powiązać z późniejszymi wydarzeniami $\mathrm{z}$ roku 549. Wtedy to Totila zgromadził 400 ploia makra, do których dołączył okręty zdobyte na Bizantyńczykach. Zgromadzone siły morskie posłużyły mu do rajdu na Kalabrię i Sycylię (w maju 549) [17]. Justynian próbował przeciwdziałać morskim rozbojom Gotów. Wysłał na Sycylię dwie nowe floty. Pierwszą pod dowództwem Liberiosa, drugą pod wodzą Artabanesa. Liberios zdołał się przedrzeć do oblężonych Syrakuz, lecz flotę Artabanesa, którą prowadził z Kefalonii, w pobliżu Kalabrii dopadł sztorm, który zegnał ją aż na Maltę [3,16,17]. Pech Bizantyńczyków sprzyjał Totili, który z łupami powrócił nie niepokojony do Italii [17]. Dla wsparcia działań na Sycylii Justynian I zabrał swoje siły morskie z rejonu Morza Adriatyckiego. Wydaje się to potwierdzać brak okrętów w Salonie, który wymusił na Bizantyńczykach pod dowództwem Narzesa marsz wzdłuż Adriatyku do Italii w roku 551, miast o wiele krótszego transportu morskiego.

Totila skorzystał z niepowodzeń floty cesarza i w roku 551 wysłał 300 okrętów z zadaniem uderzenia na Grecję. Flota Ostrogotów spustoszyła Korfu i Epir, wyłapując po drodze statki które płynęły z zapatrzeniem dla przygotowującego się do uderzenia na Italię korpusu Narzesa [3,17]. W międzyczasie Indulf dalej oblegał Ankonę. Na pomoc oblężonemu miastu przybył wraz z 38 okrętami Jan, poprzednik Narzesa, z Salony. Doszło do bitwy morskiej między Bizantyńczykami a Gotami pod Senigallia z której zwycięsko wyszli ci pierwsi. Indulf zbiegł wraz z 11 okrętami, które rozkazał spalić by te nie wpadły w ręce ludzi cesarza [3,17]. Porażka spod Senigalli nie zmieniła zbytnio rozkładu sił na morzu, Goci mieli ciągle przewagę. Świadczą o tym dalsze posunięcia Totili, którego flota zajęła Korsykę i Sardynię. Podwładni cesarza próbowali zapobiec tym działaniom Gotów, lecz ich siły morskie 
były zbyt niewielkie, aby skutecznie pokrzyżować szyki ludziom Totili [16,17]. Do końca wojny flota cesarska odgrywała już marginalną rolę w działaniach wojennych. Goci mieli pełne panowanie na Morzu Śródziemnym, aż do klęski pod Mons Lactarium. Wtedy to Narzes przekupił cześć gockich dowódców i ich flota przeszła na jego stronę [3,17].

Z końcem wojny z Ostrogotami wiążą się również działania wojsk bizantyńskich $\mathrm{w}$ Hiszpanii. Na początku lat pięćdziesiątych VI wieku w królestwie Wizygotów doszło do buntu Atanagilda wymierzonego w Agilię, miejscowego władcę. Atanagild lub Agilia zwrócił się o pomoc dla Justyniana [34,35]. Bardziej prawdopodobne jest to że uczynił to Agila, zagrożony przez Atanagilda. Bizantyńczycy przybyli drogą morską, po czym opanowali południową i południowo-wschodnią cześć półwyspu [36]. Reakcją na przybycie wojsk Justyniana był mord na Agili, który stał się ofiarą jego konkurenta. Atanagild przez resztę swego panowania walczył z próbującymi utrzymać swój stan posiadania Bizantyńczykami [38]. Nie wiemy, co zamierzał osiągnąć Justynian wplątując się $\mathrm{w}$ walki wewnętrzne $\mathrm{w}$ Hiszpanii i jakie środki przeznaczył na ten cel. Być może zależało mu na zabezpieczeniu prowincji afrykańskich, przed ewentualnym atakami Wizygotów. Flota i wojska przerzucone na półwysep pochodziły może z Sycylii lub Afryki Północnej.

\section{WNIOSKI}

Justynian Wielki przez kilkadziesiąt lat swojego panowania prowadził wojny na frontach dość odległych od cesarstwa, takich jak Afryka Północna, Sycylia, Italia czy wreszcie Półwysep Iberyjski. Do walk i późniejszego utrzymania tych regionów niezbędna była flota. Cesarz zbudował siły morskie nie jako od podstaw, rozbudowując to co otrzymał po swoich poprzednikach. Opierał się na stoczniach prowincji takich jak Egipt, czy Cylicja, jak również na tej najważniejszej, która znajdowała się w Konstantynopolu. W jego działaniach próżno jednak szukać jakieś szerszej polityki morskiej, czy planu budowy stałej marynarki wojennej. Gdy flota była potrzebna budował ją, lub co bardziej prawdopodobne tworzył w oparciu o zarekwirowane jednostki. Niestety Justynian nie potrafił dobierać sobie odpowiednich podkomendnych w działaniach na morzu. Zarówno jego wywiad morski, jak i dowódcy floty, nie byli najlepsi, o czym świadczy ilość utraconych przez warunki atmosferyczne czy raczej nieznajomość wód przybrzeżnych okrętów, o których słyszymy w czasie działań, szczególnie tych wymierzonych w Ostrogotów. Bizantyńczykom pomagał przypadek, jak również błędy władców Wandali czy Gotów, którzy nie przywiązywali zbyt wielkiej wagi do spraw morskich i utrzymania własnych sił morskich. Trzeba stwierdzić stanowczo, iż flota którą stworzył Justynian była tylko cieniem dawnej floty rzymskiej. Gdy napotykała przeciwnika, który dysponował przewagą liczebną i doświadczonymi żeglarzami, tak jak miało to miejsce w wypadku Totili czy Indulfa, nie była w stanie podjąć z nim równej walki. Oddanie inicjatywy Gotom na Adriatyku, czy na Morzu Tyrreńskim, jakie miało miejsce w czasie walk z Totilą nie wystawia zbyt dobrego świadectwa zarówno cesarzowi, jak i jego dowódcom. Do utrzymania tak rozległego opanowanego przez wojska Justyniana obszaru, niezbędna była silna i sprawnie działająca flota, a takiej niestety cesarz nie posiadał. I taką spuściznę zostawił swoim następcom.

Nie powinniśmy się dziwić, że po jego śmierci, od 568 roku Longobardowie w tak gładki sposób opanowali niemal cały Półwysep Apeniński. Istniejąca flota cesarska nie była w stanie w żaden sposób im zagrozić. Wyjątkiem był egzarchat Rawenny, który przetrwał dla tego, że jego mieszkańcy zbudowali w latach osiemdziesiątych VI wieku własną flotę, która zapewniła im stabilne połączenie $\mathrm{z}$ cesarstwem, jak również pomagała $\mathrm{w}$ walkach $\mathrm{z}$ 
Longobardami [3]. Bizantyńskie prowincje w Hiszpanii spotkał niemal taki sam los, jak Italię. Istniało jednak jakieś połączenie, którym do Hiszpanii docierali żołnierze i zaopatrzenie. Dopiero około 570 roku wizygocki król Leowigild zajął Malage i Medina Sidonię, lecz Kartagena pozostała w rękach Bizantyńczyków do początków VII wieku [38].

Konstantynopol mimo utraty części tych wysuniętych placówek, dalej interesował się sytuacją $\mathrm{w}$ tym regionie $\mathrm{i}$ był $\mathrm{w}$ stanie zagrozić Wizygotom interwencją zbrojną $\mathrm{z}$ Afryki Północnej, czy wysp na Morzu Śródziemnym, z czym mamy do czynienia w latach osiemdziesiątych VI stulecia [37]. Ciężar utrzymania połączeń morskich spadał zatem na barki namiestników poszczególnych prowincji, podobnie jak utrzymanie i budowa lokalnych sił morskich. Trzech następców Justyniana I bardziej trapiła sytuacja na wschodzie cesarstwa i Bałkanach, niż kwestie dotyczące polityki morskiej związanej z Morzem Śródziemnym. Flota była im potrzebna, ale na Dunaju i Morzu Czarnym, leżących bliżej terenu działań i na Morzu Egejskim, którym do stolicy transportowano dobra płynące z prowincji wschodnich.

\section{References}

[1] Courtois C., Les Vandales et l'Afrique, Paris, 1955.

[2] Strzelczyk J., Wandalowie i ich afrykańskie państwo, Warszawa, 1992.

[3] Pryor J.H.,JeffreysE.M., The Age of Dromon, Leiden, 2006.

[4] Hydatius, The Chronicle of Hydatius and the Cosularia Constantinopolitana: two contemponary accounts of the final years of the Roman Empire, ed. R.W. Burgess, Oxford, 1993.

[5] Priskos, History, in: R.C. Blockley, The fragmentary classicising historians of the Later Roman Empire: Olimpiodorus, Prisus and Malchus, Vol 2: text, translations and historiographical notes, Liverpool, 1983.

[6] De Souza Ph., Piraci w świecie grecko-rzymskim, thum. J. Lang, Zakrzewo, 2008.

[7] Wolińska T., Sycylia w polityce Cesarstwa Bizantyńskiego w VI-IX wieku, Łódź, 2005.

[8] Theophanes Confessor, Chronographia, ed. C. de Boor, vol. I, CSHB 28, Lepzig ,1883.

[9] Jankowiak M. , Bizancjum a kryzysy sukcesyjne w cesarstwie zachodniorzymskim w ostatnich latach jego istnienia, w: Chrześcijaństwo u schyłku starożytności. Studia źródłoznawcze, vol.3 , ed. E. Wipszycka, T. Derda, Kraków, 2000.

[10] Malchos of Philadelphia, Byzantiaka, w: R.C. Blockley, The fragmentary classicizing historians of the Later Roman Empire, Liverpool, 1983.

[11] Eickhoff E., Seekrieg und Seepolitik zwischen Islam und Abendland, Berlin, 1966.

[12] Bonino M., Archeologia navale, Storia di Ravenna, II.1, Ravenna, 1991, s. 40-41.

[13] Christides V., Graeco-Arabica 1 (1982) 61-62.

[14] Dolley R., Journal Roman Studies 38 (1948) 47-53.

[15] Agnellus, Liber pontificalis ecclesiae Ravennatis, ed. O. Holder Egger, in: MGH ScriptRerLeg, 303. 
[16] Wolfram H., Historia Gotów, przekł. R. Darda-Staab, I. Dębek, K. Berger, WarszawaGdańsk 2003,

[17] Procopius, De Bellus, ed. H.B. Dewing, Cambridge 1979, Vol. 2-5.

[18] Manfroni C., Storia della marina italiana dalle invasioni barbariche al Trattato di Nifeo(anni di C.400-1261), Milan, 1970.

[19] Marcellinus Comes, Chronicon, ed. T. Mommsen, Berlin, 1894.

[20] Bury J. B., History of the Later Roman Empire: From the Death of Theodosius I to the Death of Justinian, Volume 1, Dover, 1958.

[21] Martindale J. R. , Morris J., The Prosopography of the Later Roman Empire - Volume II, $A D$ 395-527, Cambridge, 1980

[22] Lewis A. R. , Naval Power and Trade in the Mediterranean A.D. 500-1100, Priceton, 1951.

[23] Ioannis Malalae Chronographia, CFHB, ed. B.G. Niebuhrii, Bonn, 1831.

[24] Constantine Porphyrogenetius Excepta Historica, ed. De Boor, Berlin, 1906.

[25] Cassiodorus, Variarum librii XII, ed. A. J. Fridh, CCSL 96.

[26] Vasilev A.A, Justin the First, Cambridge-Massachusetts 1950.

[27] Prokop, Vandalenkriege, ed. O. Veh, München, 1971.

[28] Baker J. W. , Justinian and the Later Roman Empire, Wisconsin, 1960.

[29] Evans J. A. S., Byzantion 47 (1977) 380-382.

[30] Corpus Inscriptorum Latinarum, Inscriptiones Bruttiorum, Lucaniae, Campaniae, Siciliae, Sardiniae, Pars 2, nos. 6976-8422 (Siciliae, Sardinia), v. X, Berlin, 1989.

[31] Clover F., Historia 48 (1999) 241.

[32] Günther L. M. , Nordafrika als Wirtschaftsfaktor im Oströmischen Reich unter Justinian I, in: L'Africa romana. Atti del'VIII convegno di studio. Cagliari, 14-16 dicembre 1990, a cura di Attilio Mastino, Vol. 1, Sassari, 1991, 369.

[33] Evans J. A. S. , The Age of Justinian, London ,1996.

[34] Jordanes, De orgine actibusque Getarum, ed. T. Mommsen, in: Iordanis Romana et Getica, MGHAA v.1.

[35] Isidorus, Historia Gothorum, in: C. Rodriguez, Les Historias de los Godos, Vandalosy Suevos de Isidoro de Sevilla, Leon, 1975, 248.

[36] Collins R., Hiszpania w czasach Wizygotów 409-711, thum. J.Lang, Warszawa, 2007.

[37] Goffart W., Traditio 13 (1957) 75-118.

[38] C. Cardelle de Hartmann, CCSL 173A (2002) 61.

[39] Krupczyński P., Trudności zachodnich wypraw Belizariusza, Łódź, 1980. 